\title{
Timeline of COVID-19 and its therapeutics in the United States.
}

Austin Cusick MS-IV¹, Pankaj Bansal MD²*, Bhavin Sonani MD ${ }^{3}$, Amandeep Goyal MD

${ }^{1}$ Ohio University Heritage College of Osteopathic Medicine. 35 W Green Dr, Athens, OH 45701.

${ }^{2}$ Mayo Clinic Health System. 1400 Bellinger Street, Eau Claire, WI - 54701.Phone: 773-899-4590, ORCID ID: 0000-0001-6315-6879

${ }^{3}$ HSHS St John's Hospital. 800 E Carpenter St, Springfield, IL 62769.

4: University of Kansas Medical Center. 3901 Rainbow Blvd, Kansas City, KS 66160.Phone: 740-434-8258, ORCID ID: 0000-0001-6070-1747

*Corresponding Author: Pankaj Bansal, Mayo Clinic Health System. 1400 Bellinger Street, Eau Claire, WI - 54701.Phone: 773-899-4590, ORCID ID: 0000-0001-6315-6879.

Received date: August 18, 2020; Accepted date: September 04, 2020; Published date: September 07, 2020

Citation: Austin C, Pankaj B, Bhavin S, Amandeep G. (2020) Timeline of COVID-19 and its therapeutics in the United States. International Journal of Clinical Case Reports and Reviews. 3(3); DOI: 10.31579/2690-4861/051

Copyright: (C) 2020 Pankaj Bansal, This is an open-access article distributed under the terms of the Creative Commons Attribution License, which permits unrestricted use, distribution, and reproduction in any medium, provided the original author and source are credited.

\begin{abstract}
The novel coronavirus was first discovered and reported in December 2019. Later termed the Severe Acute Respiratory Syndrome Coronavirus-2 (SARS-COv-2) virus, rapid spread was detected in China. Overtime, SARS-COv-2 spread to various other countries requiring swift intervention on a global scale. As infection spread, several therapeutics have been investigated for Coronavirus Disease- 2019 (COVID-19), including remdesivir, lopinavir/ritonavir, hydroxychloroquine, dexamethasone, etc. Furthermore, rapid investigation and construction of several potential vaccines have begun, some of which are in late stage testing. We present a concise timeline representing the evolution of COVID-19, therapeutic trials, and vaccine development. Ultimately, evident by the overall poor efficacy of several medications investigated so far, vaccination success remains the most likely effective step to combat COVID-19.
\end{abstract}

Keywords: covid-19, United States

\section{Introduction}

The world is going through unprecedented times as the novel Severe Acute Respiratory Syndrome Coronavirus-2 (SARS-CoV-2) virus has continued its spread globally. It was in December 2019 that China alerted the World Health Organization (WHO) of a cluster of cases of pneumonia of unknown origin in the Wuhan in Hubei province [1]. While it was initially postulated that the human-to-human transmission may not exist, within a few days, the WHO confirmed the human-to-human transmission of the virus. Thailand reported the first imported case outside China on January 13th, 2020. On January 20th, the first case of 2019 novel coronavirus (2019-nCoV) was reported in the United States [2]. By January 30th, China had reported more than 9,000 cases with more than 200 deaths, and cases were reported from several other countries including Thailand, Japan, Taiwan, Singapore, Vietnam, Nepal, Finland, Italy, South Korea, India, Australia, France, Malaysia, and Canada [1]. It was on January 30th that the WHO declared the 2019-nCoV as a public health emergency of international concern [1].

The first mortality in the United States was reported on February 6th, 2020 from California [3]. On February 11 2020, the WHO announced the formal name Coronavirus Disease- 2019 (COVID-19) [4]. While the initial caseload and deaths were mostly in China, by the end of February 2020, Iran and European countries including Italy and France started reporting rising numbers of cases and deaths from COVID-19. By March 1st, most cases in the United States were from Washington State, and new cases were being reported from other states including New York. On March 11th, the WHO declared COVID-19 a pandemic and on March 13th, the United States declared the pandemic to be a national emergency [1].

The caseload in the United States crossed 100 on March 3rd 2020, and by March 19th 2020, the cases had surpassed 10,000 and on March 26th 2020, the United States overtook China to become the country with the most number of cases worldwide with more than 86,000 cases. It took less than a week to surpass 200,000 cases in the United States, and most of the cases were being reported from the New York area. On April 11th, 2020, with more than 19,000 deaths reported, the United States became the country with most deaths worldwide and by the end of April 2020, there were more than 1 million cases of COVID-19 in the United States [1]. This number steadily climbed in the United States and world eventually reaching 1,507,773 cases and 90,113 deaths in the United States, and 4,722,319 cases and 313,268 deaths worldwide by May 17th 2020 [5, 6]. Since April 2020, the United States has been the world leader in both the number of cases, as well as the number of deaths. ${ }^{5}$ As of August 5th 2020, when comparing the case-fatality ratios, the United States places 24 with the United Kingdom taking the lead. When investigating per capita death rates, the United States places ninth with Belgium placing first [7]. As of August 9th, the United States had 5,199,444 total cases with 165,617 deaths (Figure 1) [8,9]. 


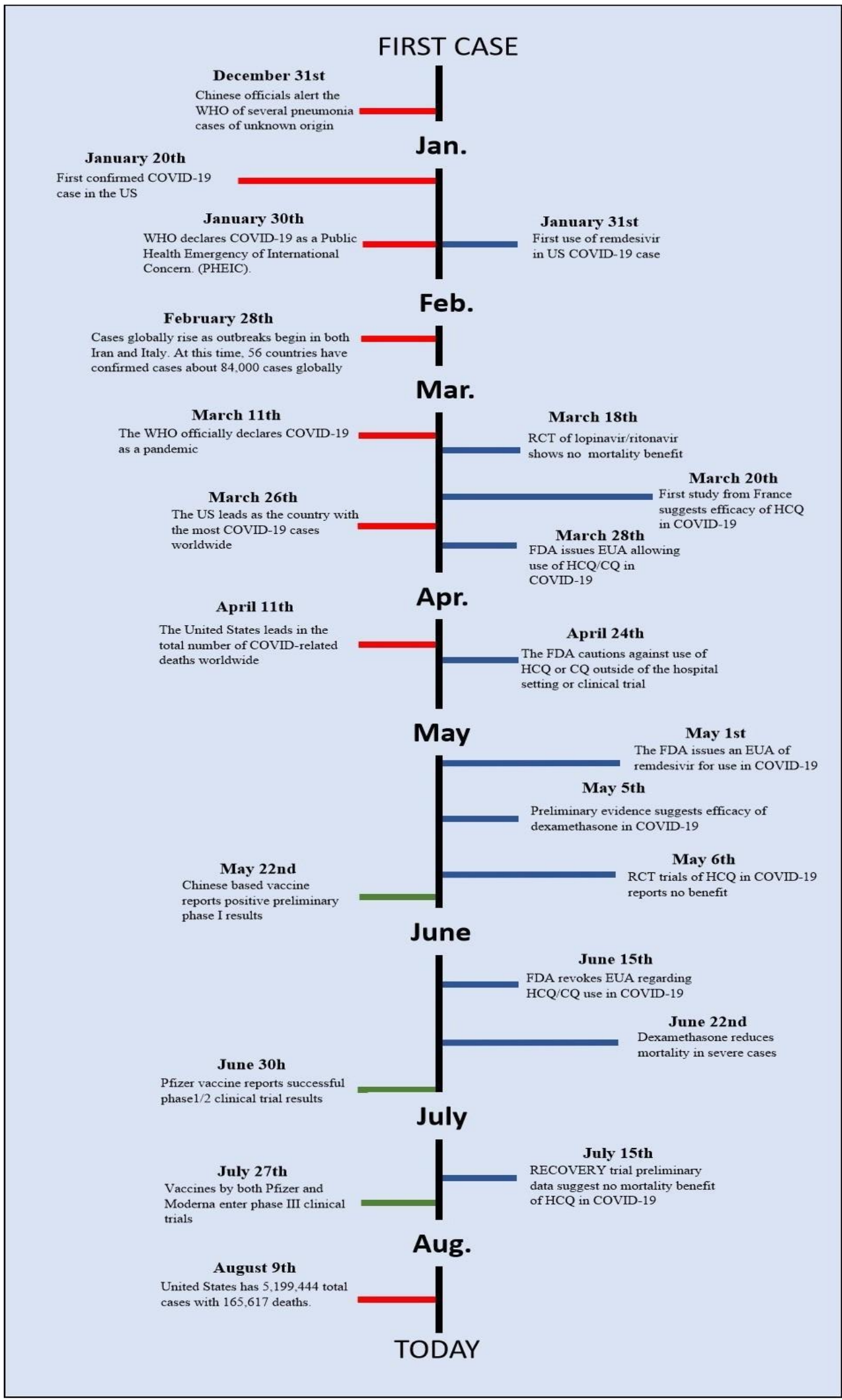

Figure 1: Timeline of COVID-19 and its therapeutics in the United States. 
To date, there is no definitely proven effective therapeutic option for COVID-19. Initial attempts by scientists across the world have focused on finding therapeutic options already approved for another indication, and antiviral agents including lopinavir/ritonavir gained popularity owing to the in vitro efficacy against the Sudden Acute Respiratory Syndrome Coronavirus (SARS-CoV) and potential efficacy shown previously against Middle Eastern Respiratory Syndrome Coronavirus (MERS-CoV) and Sudden Acute Respiratory Syndrome (SARS). However, further clinical trials failed to show any efficacy of lopinavir/ritonavir in COVID$19[10,11]$

Similarly, antimalarial agents including chloroquine and hydroxychloroquine were one of the initial agents that gained interest as a therapeutic option after data from in-vitro studies and a cohort study from France showed potential antiviral efficacy [12]. The President of the United States in a press release famously cited this study [13], and antimalarial agents gained fame as potential game-changers. However, more well-performed studies and randomized controlled clinical trials soon followed and did not show any benefit of chloroquine or hydroxychloroquine in COVID-19, and the FDA retracted the emergency authorization for use of hydroxychloroquine in COVID-19 in June 2020 $[11,14-16]$

One of the antiviral agents that has shown promise is remdesivir, a broadspectrum antiviral agent. While initially developed for the treatment of hepatitis $\mathrm{C}$, remdesivir has shown activity against SARS and MERS in past in vitro assays $[17,18]$. This sparked investigation for a possible role in COVID-19. This medication was used on the first known COVID-19 case of the United States. ${ }^{19}$ After successful evidence showing moderate benefit especially in shortening the length of hospital stay in patients admitted with COVID-19, the FDA issued an emergency use authorization for remdesivir. It is currently the only drug still granted this approval for use in COVID-19 [17, 20-22].

COVID-19 is associated with excessive uncontrolled release of proinflammatory cytokines in severe cases, and several anti-inflammatory and immunomodulatory agents have been investigated, with trials ongoing on others. Data from the Rheumatology COVID registry revealed that patients who are already on moderate to high doses of corticosteroids have a higher risk of more severe COVID-19 infection $[23,24]$. However, when used in more severe cases already needing oxygen, dexamethasone was shown to reduce mortality $[25,26]$. Initial and preliminary data on other anti-inflammatory and immunomodulatory agents including interleukin-6 and interleukin-1 inhibitors (tocilizumab and anakinra respectively) have shown promising results, with further trials ongoing. Sarilumab, another interleukin-6 inhibitor did not show any benefit in COVID-19, while trials on colchicine, baricitinib, and antitumor necrosis factor medications are ongoing [27-29].

With no definite therapeutic agent still available, the hopes to overcome the pandemic rely mostly on a safe and effective vaccine. The goal of vaccination is to stimulate a protective immune response using viral genetics, proteins, or entire inactivated virions. Initial investigation of vaccines began rapidly, and several pharmaceutical companies have reached various stages of clinical trials by now. Many vaccine candidates have been established in all various roles described. Notably, Chinese based vaccines demonstrated a positive preliminary phase 1 results as early as May 22nd. Other vaccines followed closely with their own successful preliminary positive results. At this time, few vaccine candidates have entered phase III clinical trials [30-35]. possible viral mutations could interfere with the overall effectiveness of future vaccines, and further ongoing research about the viral evolution will be critical to investigate this complicating factor [36].
The United States-based Moderna vaccine that is mRNA based entered phase III in July 2020. Another mRNA based vaccine from the United States-based Pfizer/BioNTech has reached Phase II/III. China-based Sinopharm and Sinovac biotech have entered phase III with their vaccines using attenuated whole-virus inoculation, while the China based CanSinoBio and AstraZeneca have entered phase III with their viral vector based vaccines [30-35]. It may not be until 2021 that an effective and safe vaccine may be available for widespread use, and with no definite therapeutic option available. To date, the only way to mitigate the virus is by prevention precautions and social distancing.

\section{Conclusion}

Currently, no medications have sufficiently stood out as an outstanding therapeutic option for COVID-19, and trials on several potential vaccine candidates are ongoing worldwide, with a hope for a successful vaccine available for widespread use by 2021. Implementing prevention precautions remains as the primary method for limiting the spread of SARS-CoV-2.

\section{Author contributions}

All authors have made substantial contributions to the creation of this manuscript including writing the initial manuscript, literature review, and reviewing, and revising the final version. The final manuscript has been reviewed and approved by all authors.

\section{Financial disclosure and conflict of interest statement}

We confirm that the authors have no financial disclosures, competing interests, and conflict of interest. The study has not received any financial support or other benefits from commercial sources for the work reported on in the manuscript. The manuscript represents the original work of the authors and identical or similar work has not been published or submitted for publication elsewhere.

\section{Data sharing statement}

There is no data in this work.

\section{References}

1. Kantis C, Kiernan S, Bardi J. (2020) Updated: Timeline of the coronavirus. Accessed May 17.

2. First confirmed case of COVID-19 in the United States is diagnosed in Snohomish County on January 20, 2020.

3. 1st Known U.S. COVID-19 Death Was Weeks Earlier Than Previously Thought.

4. Naming the coronavirus disease (COVID-19) and the virus that causes it.

5. Coronavirus statistics May 17th.

6. Situation Report-118. Accessed August 17, 2020.

7. Charts how the US ranks on COVID-19 deaths per capita and by case count.

8. Situation Report-202. Accessed August 17, 2020.

9. Coronavirus statistics August 9th. Accessed August 9, 2020.

10. Cao B, Wang Y, Wen D, et al. (2020) A Trial of LopinavirRitonavir in Adults Hospitalized with Severe Covid-19. N Engl J Med.382 (19):1787-1799.

11. WHO discontinues hydroxychloroquine and lopinavir/ritonavir treatment arms for COVID-19.

12. Gautret P, Lagier J-C, Parola P, et al. (2020) Hydroxychloroquine and azithromycin as a treatment of COVID-19: results of an openlabel non-randomized clinical trial. Int J Antimicrob Agents.

13. Remarks by President Trump, Vice President Pence, and Members of the Coronavirus Task Force in Press Briefing. 
14. Horby P, Mafham M, Linsell L, et al. (2020) Effect of Hydroxychloroquine in Hospitalized Patients with COVID-19: Preliminary results from a multi-centre, randomized, controlled trial. medRxiv.

15. Tang W, Cao Z, and Han M, et al. (2020) Hydroxychloroquine in patients with mainly mild to moderate coronavirus disease 2019: open label, randomised controlled trial. BMJ.

16. Skipper CP, Pastick KA, Engen NW, et al. (2020) Hydroxychloroquine in Nonhospitalized Adults with Early COVID-19: A Randomized Trial. Annals of Internal Medicine.

17. Wang M, Cao R, Zhang L, et al. (2020) Remdesivir and chloroquine effectively inhibit the recently emerged novel coronavirus (2019-nCoV) in vitro. Cell Res.30 (3):269-271.

18. Agostini ML, Andres EL, Sims AC, et al. (2018) Coronavirus Susceptibility to the Antiviral Remdesivir (GS-5734) Is Mediated by the Viral Polymerase and the Proofreading Exoribonuclease. mBio. 9(2).

19. Holshue ML, DeBolt C, Lindquist S, et al. (2020) First Case of 2019 Novel Coronavirus in the United States. N Engl J Med.382 (10):929-936.

20. NIH clinical trial of remdesivir to treat COVID-19 begins. Accessed August 9, 2020.

21. Remdesivir EUA by FDA. Accessed August 16, 2020.

22. Grein J, Ohmagari N, Shin D, et al. (2020) Compassionate Use of Remdesivir for Patients with Severe Covid-19. N Engl J Med.382 (24):2327-2336.

23. Moderate, high dose steroids linked to more severe COVID-19. Accessed August 17, 2020.

24. COVID-19 Global Rheumatology Alliance. Accessed August 17, 2020.

25. Horby P, Lim WS, Emberson J, et al. (2020) Effect of Dexamethasone in Hospitalized Patients with COVID-19: Preliminary Report. medRxiv.
26. Fadel R, Morrison A, Vahia A, et al. (2020) Early Short Course Corticosteroids in Hospitalized Patients with COVID-19. medRxiv.

27. Luo P, Liu Y, Qiu L, Liu X, Liu D, Li J. (2020) Tocilizumab treatment in COVID-19: A single center experience. J Med Virol. 92(7):814-818.

28. Dimopoulos G, de Mast Q, Markou N, et al. (2020) Favorable Anakinra Responses in Severe Covid-19 Patients with Secondary Hemophagocytic Lymphohistiocytosis. Cell Host Microbe. 28(1):117-123.

29. Della-Torre E, Campochiaro C, Cavalli G, et al. (2020) Interleukin6 blockade with sarilumab in severe COVID-19 pneumonia with systemic hyperinflammation: an open-label cohort study. Ann Rheum Dis. published online July 3.

30. Moderna launches new trial. Accessed August 9, 2020.

31. Coronavirus vaccine tracker. Accessed August 9, 2020.

32. Mulligan MJ, Lyke KE, Kitchin N, et al. (2020) Phase 1/2 Study to Describe the Safety and Immunogenicity of a COVID-19 RNA Vaccine Candidate (BNT162b1) in Adults 18 to 55 Years of Age: Interim Report. medRxiv.

33. Moderna Announces Phase 3 COVE Study of mRNA Vaccine Against COVID-19. Accessed August 17, 2020.

34. PFIZER AND BIONTECH CHOOSE LEAD MRNA VACCINE CANDIDATE AGAINST COVID-19 AND COMMENCE PIVOTAL PHASE 2/3 GLOBAL STUDY. Accessed August 17, 2020.

35. Jackson LA, Anderson EJ, Rouphael NG, et al. (2020) An mRNA Vaccine against SARS-CoV-2 - Preliminary Report. N Engl J Med. Published online July 14.NEJMoa2022483.

36. Hegazy A, Hegazy R. (2020) COVID-19: Virology, Pathogenesis and Potential Therapeutics. Afro-Egyptian Journal of Infectious and Endemic Diseases.10 (2):93-99.
This work is licensed under Creative Commons Attribution 4.0 License

To Submit Your Article Click Here: Submit Article

DOI: $10.31579 / 2690-4861 / 051$
Ready to submit your research? Choose Auctores and benefit from:

* fast, convenient online submission

* rigorous peer review by experienced research in your field

* rapid publication on acceptance

* authors retain copyrights

* unique DOI for all articles

* immediate, unrestricted online access

At Auctores, research is always in progress.

Learn more www.auctoresonline.org/journals/international-journal-ofclinical-case-reports-and-reviews 